\title{
FUNERAL TRADITIONS IN THE MAT LOU ETHNIC CULTURE IN LILINTA VILLAGE, RAJA AMPAT ISLAND
}

\author{
Muhamad Yusuf ${ }^{\left({ }^{*}\right)}$, Enos Rumansara (2), Marlina Flassy (3), Erfin Wijayanti ( ${ }^{(4)}$ \\ ${ }_{1,4}^{1}$ Institut Agama Islam Negeri Fattahul Muluk, Papua, Indonesia. \\ ${ }^{2,3}$ Cenderawasih University, Papua, Indonesia.
}

\section{ARTICLE INFORMATION

$\begin{array}{ll}\text { Submitted } & : 31^{\text {st }} \text { August } 2021 \\ \text { Review } & : 01^{\text {st }} \text { October } 2021 \\ \text { Accepted } & : 06^{\text {th }} \text { December } 2021 \\ \text { Published } & : 18^{\text {th }} \text { December } 2021 \\ \text { Available Online }: \text { December } 2021\end{array}$

\section{KEYWORDS}

Tradition; Ritual; Death; Mat Lou Ethnic; Culture

\section{CORRESPONDENCE}

*E-mail: joesoef1974@gmail.com

\begin{abstract}
A B S T R A C T
This study aims to determine the implementation of the funeral ceremony in the Mat Lou ethnic community in Lilinta Village, West Misool District, Raja Ampat Islands. This research was qualitative using the social phenomenology paradigm with a flow chart model analysis. Results of this research: The culture of Raja Ampat community, especially in Lilinta village, which is Islam as a majority, has been through a culture diffusion and transformed with the existing local culture to produce a new culture. The cultures which are still conducted in the performance of various death are Tahlilan that has differences on its implementation, lifting the corpse using Koi (beds) where the other region in Indonesia those activities are conducted using coffins, the differences in making tombstone and also bones bath (Sof Kabom) which has various myth symbols in it. Immigrants have a role in spreading culture to bring up the assimilation of new cultural traits and elements of the Lilinta community in the form of other rituals that complement the death ritual
\end{abstract}

\section{A. INTRODUCTION}

$\mathrm{T}$ he Raja Ampat Islands are an area consisting of several large islands and small islands that form an archipelago divided into two large rooms in the south and the north. The large islands are Waigeo Salawati, Misool, and Batanta, which into the Raja Ampat Regency area. The Misool island has two different ethnic groups, commonly called Mat Lou or Mat Lolo (coastal people), they inhabit coastal areas, including Lilinta village, Gamta, Fafanlap, Yellu, Usaha Jaya, Harapan Jaya, different case with Mat Bat (Landlord), That is people who inhabit areas that are slightly indented/highlands. An example is the people of Magei village.

Lilinta village, is influenced by immigrants who come, thus forming a new culture that is still preserved. The people of the Raja Ampat Islands easily accept people from outside compared to other Papua regions because they have experienced the development of civilization earlier than other Papua regions. Wallace (2015,p.547) said: The Gorong people (I have lived with them for a month) are traders. Every year, they visit the Tanimbar, Kei and Aru Islands and the entire Northwest coast of Papua from Oetanata to Salawati and the islands of Waigeo and Misool.

Lilinta village has experienced cultural diffusion and transformed with the local culture so that sometimes it produces new cultures. One of the cultures of Lilinta village, where the majority of the community is Muslim, which is still perform funeral rituals. When one of its citizens dies, funeral rituals are performing. The implementation of the ritual has several differences with other regions in the archipelago. These rituals consist of Tahlilan, which has differences in its performance, Koi (bed), which is lifting the corpse using a bed, whereas in other regions in Indonesia, lifting the corpse using rod brackets or Coffins, especially in this modern era are rarely found lifting corpses using beds, differences in making headstones, and bone baths 
(sof kabom) which complete the funeral rituals of the people of Lilinta village. The implementation of the ritual mixed between customs, religion, and local beliefs mingled into one, where the people of the Lilinta village still carry it out until now. Gradually these traditions will disappear with the times. This tradition is starting to fade, as in the ordinance, because tradition is oral and carried out from generation to generation. This study was conducted to find out about the implementation of the funeral ceremony for the Mat Lou ethnic community in Lilinta Village, West Misool District, Raja Ampat Islands.

Literature studies include Class struggles and social status in the Maulidan ritual in the Krajen Mlaran hamlet, where the Krajen community carries out the Maulidan memorial ritual using blessings with a process that relies on actions that tied from the interaction of a group of students with the surrounding community that considers the cultural values of the surrounding community (Arwani 2013,p.76).

(Suwito et.al, 2015) Said that Variations on the tradition of death by distance and evolution. There are various main views: first, Javanese Muslims in understanding and carrying out death rituals are based on a strong basis that respects those who live and is a symbolic dimension with other worlds. Second, Javanese Muslims understand that death is the way to Allah, so that everyone should be in a state of purity and still believe that only worship Allah.

The funeral tradition of the Ayamaru community in Meibrat Regency, West Papua Province, divides funeral traditions into three forms: people who die in normal circumstances, people who die from causes and effects, and people who die unusually. Where the coveted value of an ethnic group/community usually has two dimensions, such as good and bad. According to other people's assessment of activities that are usually carried out by the community in question, what is bad. On the other hand, the community concerned thinks that what is wrong is good for them. (Yaam. et.al, 2012,p.53).

(Karim, 2017) Said: Death is an important event that is very moving in a life story. Which cannot ignore such an event. The tradition of death always gives birth to rituals that have differences, namely sacred rituals. Javanese Muslims have special rituals. The ritual has been acculturation between Hinduism, Buddhism and Islam continuously since the past, where is it now a new tradition has emerged. This tradition is different from that found in other countries.

In contrast to previous research, this study elaborate on the contextual issues of religion in a community in Lilinta Village, West Misool District, Raja Ampat Islands, which are related to the struggle between customs, local wisdom, religion, and local beliefs in funeral traditions.
The theoretical frameworks by Emile Durkheim in (M. Yusuf, Sahudi, M. Sileuw, L. Safitri, 2021) Explain: Religion will remain a social fact, a social reality that science cannot deny. In other words, religion will adapt and change itself and will not disappear. Durkeim views religion or sacred as something that requires people to come together to act together, And as a consequence, that strengthened through individual and collective abilities in dealing with joys and sorrows of everyday life.

Hans-Georg Gadamer in (Gusmao, 2012,p.129) states that religion tries to offer a vision of shared consciousness or a view of the world of life (Lebenswelt). Geertz in (Pals, 2012,p.342) stated that Religion is a system of symbols that aims to create intense feelings and motivations that are easily pervasive and not easily lost in a person by forming a conception of a general procedure of existence and attaching this conception to accurate projections and ultimately these feelings and motivations become a unique reality.

(Ahimsa-Putra, 2012,p.62) Stated that Transformation is a change that occurs at the surface level, while at a deeper level, the change does not happen. Max Weber in (M.S. Nawir, M.Yusuf, A. Kadir, 2020) explain that To approach culture is concerned with how culture places goals and actions are structured through interests and norms.

Rumansara in (Arwani, 2013,p.59) explain one of the bases for changes in the culture of a particular community group is the acceptance of a new cultural element in that community group. Rapanna in (Nurrofika \& Murdiono, 2020) explain that thoughts and values create local wisdom. The people of a region believe in norms in their environment, which contain various values, standards and belief systems, and multiple ideas.

John A. Saliba in (Sari, 2018), explain that a symbol is a form of expressive communication, having information or a message that cannot speak directly. Symbols can have meanings that do not come from experience because symbols refer to other realities outside the experience level. Langer and Geertz in (Dillistone, 2002,p.116), explain that every object, action, event, trait, or relationship can have a role as a vehicle for a conception. That conception is the "meaning" of the symbol. So the interpretation of culture is essentially the interpretation of various symbols.

Durkheim in (M. Yusuf \& M.S. Nawir, 2021), says Mechanical solidarity is solidarity defined by "sacred rights" in the society concerned more explanation: Mechanical solidarity has a permanent nature but has a significant meaning. It is based on ethnicity, values, and symbols that differentiation can develop without causing division. Siebold, A. in (Syafrita \& Murdiono, 2020) states that solidarity is a shared feeling among individuals who are in harmony with a group to produce a sense of brotherhood and friendship based on an 
understanding of caring and kinship, established through compactness in an environment or group.

(Pals, 2012,p.159), revealed: The function of religious ritual is far more critical than this belief will provide an opportunity for every community member to renew their commitment to the community, reminding that under any circumstances, they will always depend on the community, like as a society also depends on their existence.

William Sewell Jr in (Turner, 2012,p.132) explains the sources of habitus involve "culture schemes" which include several deep binaries or paired oppositions emphasized by structuralism and post-structuralism in addition to various conventions of recipes, scenarios, principles of action, and habits in the form of speech and body movements that are built and developed with these fundamental tools. Habitus obeys a practical logic (practical logic), such as the fuzzy logic of things, the logic of "more or less." (de l'a-peu pres), which defines a person's ordinary and everyday relationship with the world (society). (Bourdieu, 2011,p.101).

H. Emerson in (M. Yusuf, Sahudi, \& R.S. Muhandy, 2021) describes the effectiveness is a measurement that has the meaning of realizing the goals or objectives set previously. Guided by Emerson's thoughts above, The effectiveness of something means the realization of goals and objectives in line with a predetermined plan.

\section{B. METHOD}

$\mathrm{T}$ his article describes the phenomenon of the Mat Lou ethnic funeral tradition in Lilinta Village, West Misool District, Raja Ampat Islands. This tradition is unique and has differences from other regions in the archipelago. Qualitative research focuses on everyday life's meaning and subjective experiences to explain how objects and experiences are created meaningfully and communicated in everyday life.

The research site was Lilinta Village, West Misool District, Raja Ampat Regency. The research site is due to the diverse population variations that led to cultural acculturation between immigrants and natives, including funeral ceremonies. Critical instruments in the research: the people of Lilinta village, and the researchers themselves. Primary data were obtained directly from informants. Secondary data was obtained through documentation studies in the form of reports both when in the research field or in other places, which have relevance to the research object. Observations were carried out frankly and covertly, conducting data collection honestly to the data source. So that, the data source knew that the researcher was conducting the research. The researcher is dishonesty in obtaining the data that still confidential.
Conduct in-depth interviews more freely by conducting unstructured interviews. Using the flow chart analysis technique developed by Miles and Huberman in (M. Yusuf, Sahudi, \& R.S. Muhandy, 2021), analyzing data by sorting it into three parts: Data Reduction were summarizing the data; Data Display were create short descriptions; and Conclusion Drawing/verification.

\section{RESULT AND DISCUSSIONS}

\section{a. Implementation of the Mat Lou Ethnic Community Funeral Ritual in Lilinta Village, West Misool District, Raja Ampat Islands}

\section{Death Announcement}

I a death occurs in Lilinta Village, it is announced through the mosque in the village. However, because of their kinship with other areas, such as Gamta Village, Fafanlap, primarily when the person is still descended from the Mat Bat people, Then the obituary information using a cellphone, except for villages that do not receive a cell phone signal, such as Kapatcol Village, so that notice of the end of his brother is known, delivery by going to his family using a motorized boat.

The announcement of the death was carried out at the village Mosque, a group communication between a person in charge of conveying the news to the entire community in Lilinta Village, carried out spontaneously. For notification to other villages, use the interpersonal communication model between the person delivering the information and the village head or local priest. The imam or village head conveys the news of the death to all residents. They came to residents of other villages or neighboring villages such as Gamta, Fafanlap, Yellu, and others using motorized boats.

\section{Bathing the Corpse}

In the Mat Lou ethnic community in Lilinta Village, bathing the corpse is usually done by people who understand the procedure. For example, a prayer leader bathing the man, modim 1 , and the corpse's family for men. Likewise with female corpses, usually represented by female parents in Lilinta Village and their families $\left(\right.$ Muhrim $\left.^{2}\right)$. According to Islam's teachings, the Met Lou ethnic community washes the corpse, wherein religion has rules as interpretations and sources of social order that contain meaning. Religion explains the social order regulated in it to control life in society, both personal

\footnotetext{
${ }^{1}$ It is the position of assistant to the Imam when the Imam is unable to attend.

${ }^{2} \mathrm{He} / \mathrm{She}$ Is a sibling, mother or father, nephew, uncle, or blood relative either in the order above or in the order below from someone.
} 
and social. Group, so the technique of bathing the corpse is also in religious teachings.

Bathing the corpse is done in the open with a cloth-covered around the place to wash the corpse. equipment used as usual for bathing such as soap, shampoo, water in a large bucket with camphor, and preparation of a large bucket for the ablution of the body, And two or three large buckets for bathing the corpse, a dipper, cloth to cover the area used to wash the corpse, usually done in the yard, pouring it slowly on the corpse, starting with a prayer and ending with a prayer made by the prayer leader.

\section{Shrouding the Corpse}

As is the case with bathing the corpse, such as people who have the ability or know about the procedures for surrounding the corpse following Islamic teachings, It is usually done by Judge Sara ${ }^{3}$, The leader prayer, Modim, assisted by several people, family, and close relatives if the deceased is a man. For women, it is usually done by female parents in Lilinta Village and the female family ( $\mathrm{Her}$ Muhrim).

Surrounding the corpse following the instructions of Islam, religion is the interpreter of social order and at the same time a source of social order. Religion contains ideas and beliefs about the world and tends to feel and act according to opinions and beliefs. That forms a system of symbols that aim to create intense feelings and motivations that are easy to spread, not easily lost in a person by forming a conception of general procedures to be carried out in existence and attaching this conception to factual light and in the end, these feelings and motivations are seen as a unique reality carried out by Muslims in Lilinta Village by showing certain principles, formulations, and laws proclaimed by the Qur'an and the Sunnah of the Prophet in carrying out the ritual of shrouding the corpse.

Shrouding the corpse is the same as in other areas. For adults, a 12-meter long cloth for men and 15 meters for women is used, divided into two by tearing the cloth without using scissors. Each piece is divided into three parts, the core of which is 3 pieces for the outer wrapper, which is measured along the length of the body, and an extra 1 span over the toe and 1 span over the head, for the inner wrapping, 2 pieces of the shroud are provided, 1 piece for the clothes and 1 piece for the sarong, which is measured from the navel to the ankle of the corpse. Then made straps, 5 outer straps, and 3 inner straps. Cotton is also prepared. If the body that normally dies only needs 2 pillows, while for those who die abnormally, for example, an illness that oozes fluid, then 3 cotton pillows are needed.

${ }^{3}$ It is a position in the traditional Mat lou community in Lilinta Village, as the person who decides on various customary cases, but this position is also found in the Maluku region and its surroundings.

\section{Corpse Prayer}

The corpse prayer ritual for the Mat Lou ethnic community in Lilinta Village was carried out for the first time at the funeral home by the bereaved family and close relatives, who lead the prayer in the funeral prayer at home, the eldest male from the family. Then the corpse is brought to the mosque to be prayed in the congregation by the villagers, to lift the corpse not using a coffin as is usually done by the city community, but using a Koi (a bed that has been used by the corpse all his life). The Koi used to lift the bodies are decorated with white mosquito nets and given perfume and decorated, after that the people read Surah Yasin, which is carried out the morning after death, which in Misool language is called Tarantana, after Yasinan is finished, the body is washed, then the corpse is lifted to the grave by families and communities using decorated Koi, delivering corpses by reciting tahlil to the grave. The corpse was buried as soon as possible, the burial in Lilinta Village was carried out before the Djuhur prayer.

The implementation of the funeral prayer at home is an embodiment of a sense of family togetherness facing grief, and begging for the corpse in the form of a funeral prayer is an obligation by the family to pray together. Next, the corpse is brought to the mosque using Koi, accompanied by family, relatives, the people of Lilinta village to pray in the congregation. The imam in the funeral prayer in the community at the mosque is the village leader prayer. The procedure for carrying out the funeral prayer is to follow Islamic law in general. Every adult in the village community can pray the corpse together/in congregation due to facing shared sadness due to the reduced community members in the village, without coercion to pray in congregation at the mosque. With a high sense of brotherhood in social life voluntarily on the initiative of individuals as an inseparable part of society to participate in praying for the corpse, the community participates in delivering the corpse to the mosque from the funeral home together and then returning it to the burial place. This case is where the togetherness of citizens regardless of the social status attached to them in social life.

\section{Bury the Corpse}

The burial process in Lilinta Village takes place at the funeral garden in Lilinta Village. Unless the bereaved family has their funeral, the burial of the corpse in the family cemetery, Traditional leaders in Lilinta Village usually have their funeral. The grave of each corpse has a different Nissan. Men have an oval headstone, while women have a jagged monument at the end of the headstone. The difference in the shape of the headstones in Lilinta Village used by men and women has been going on for generations by the Mat Lou ethnic group in Lilinta Village. This distinction is a conception that has a 
particular interpretive meaning. This distinction proves the value of the pattern, which is one form of the characteristics of the human body so that the tomb symbol for men and women is formed that distinguishes the shape of the tombstone in Lilinta Village from other places, which is used until now and can see the local community as the embodiment of symbols that exist in humans.

After the funeral, they were reading the prayer for the corpse, led by the Imam of Lilinta village, with the people present at the funeral. Sprinkled with flowers, each family left behind one by one sends prayers for the corpse, starting from the wife when the husband dies or vice versa, then the eldest child to the last child, followed by close relatives. Pray for the corpse to get relief from the torment of the grave. After that, he asked all the residents present at the funeral about the corpse's debts during his life to say that the surviving family could pay it off, so it doesn't become a burden on the corpse after the introductions returned to their respective homes waiting for the tahlil at the funeral home.

\section{Tahlilan}

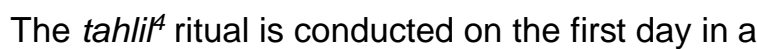
row until the seventh day, then the next day until the hundredth day, a year, two years, up to a thousand days. The habit of sending tahlilan prayers in Lilinta Village compared to other places is quite different. Still, the substance of the tahlil activities is the same, namely praying for the corpse to get a proper place by Allah S.W.T. In tahlilan activities, people do not read Surah Yasin while attending tahlilan.

Before the tahlil, the family poured water from the teapot onto the grave, intended to signal the corpse that they would send prayers to him. The corpse knows his family will send blessings to him until the 40th day, which is the belief of the Mat Lou ethnic community in Lilinta Village. With the idea that on the 3rd day, the entrails started to rot, the 7th day, entrails exploded. On the 40th day, the bones separated the meat, so Lilinta village people acted according to this idea and belief. Burning incense, or incense (Kalambak), is intended so that the spirit be around the house. In carrying out this ritual, the husband and wife who are left behind usually wait beside the Koi while reading the verses of the Qur'an, without having to take a bath for 7 days, just washing their face without combing their hair. It is a manifestation of the expression of feelings and emotions, the release of negative energy is transferred to a positive one, in reducing the burden of sadness borne by the bereaved family, personal

\footnotetext{
${ }^{4}$ It is a sentence praising the creator, the initial ruling in praying, namely Laillahaillalah (There is no other god but Allah). At the same time, the term Tahlilan is a procedure for sending prayers for people who have died in the following sequence of readings: Wasillah, Sholawat, Hamdallah, Al-lkhlas, Al-Muawizataim, AlBaqarah verses 1-5 and the last verse, the seat verse and so on.
}

and family and those who see it feel sorry for the departure of people who are very close to them.

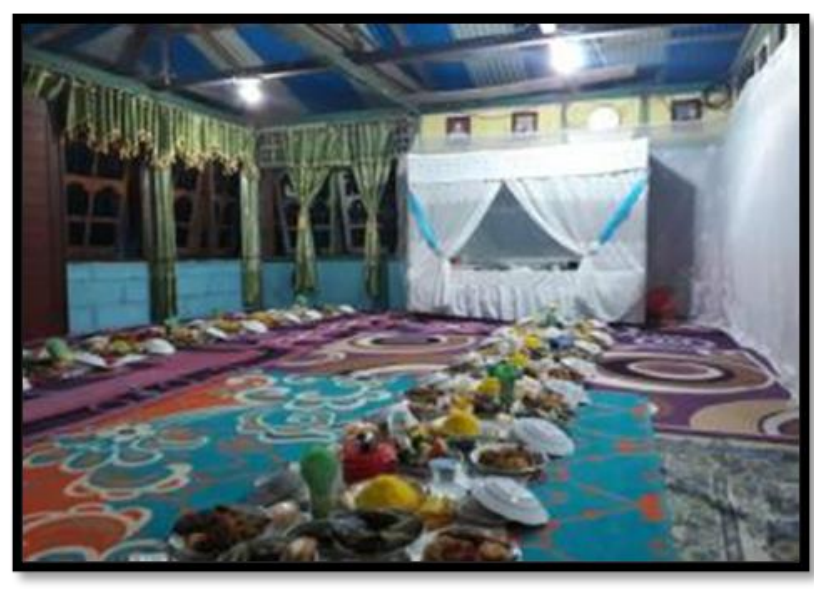

Figure 1.

Dishes to Eat in Tahlil in Front Koi (Dead Bed)

The tahlilan meal 1 to 7 days after the day of death, on odd nights: 3rd night, 5th night, and 7th night, on odd nights tahlilan is held in the morning and evening. Meanwhile, on the evening of even tahlilan, it is held twice a day, in the morning and the afternoon. On an even night, the tahlilan dish is in the form of Cakes at least 5 kinds of cakes, such as sago bia cake, lapis, sponge, and so on. The tahlilan dish on odd nights uses white and yellow rice in the shape of a Mecca dome as a symbol of the spirit's journey with prayers to trace the way of climbing to its realm, namely the afterlife. Each person/congregation present gets 1 plate of white rice, while the congregation who attends gets 1 plate for 2 people for yellow rice. Vegetables and side dishes for each gathering get 1 plate, sometimes 5 or more kinds, which usually consist of: Fish sauce, chili chicken, pickled vegetables, eggplant chili, noodles and so on. After the tahlilan is over, people can enjoy yellow rice and white rice along with side dishes and vegetables. The procedure for enjoying food dishes that the grieving host/family has provided has its uniqueness. Lilinta village every formal event is carried out without using chairs, guests who were present both men and women sat apart, lined up face to face lengthwise.

The procedure for sitting the tahlil ritual carried out by the Mat Lou ethnic community in Lilinta Village, namely folding both legs to one side of the body, is a specific pattern. The procedure for sitting the tahlil ritual carried out by the Mat Lou ethnic community in Lilinta Village, namely folding both legs to one side of the body, is a specific pattern. Positions and boundaries are symbolized correctly by the characteristics of the bodies of people present in the ritual. Having an interpretation of the signs of the human body produces meaning for the community as respect for others around them and cares for them. A person should respect himself before respecting others because one is still alive and given health by the almighty creator. 
The host serves the dish on a long white cloth, and the dish may not be returned or left on the plate. If it doesn't run out, then it must be brought home by guests. The deceased family provides plastic on their respective containers, and the dish that the host serves-got home called paksang. For the distribution, there is usually more mosque imam than other traditional elders, more traditional elders than ordinary people who participate in rituals. For the distribution, there are usually more mosque priests than other traditional elders, more traditional elders than ordinary people who participate in rituals. In formal events, betel nut (nyana), areca nut (kamacu), betel nut (lufi sut nyana) and cigarettes (tabaka) are also available, as in other areas in Papua, which in their understanding is one of the objects that are meaningful as a unifying tool for the community in welcoming guests. Different feeding is a symbol of respect for someone who has an essential role in implementing the tahlil ritual, an object, action, event, nature or relationship as a vehicle for conception in the life of the community in Lilinta Village.

Tahlilan Taram Tanah is tahlilan every morning and evening. Relatives bring assistance in the form of money, spices, food ingredients needed to implement the tahlilan without any coercion in assisting the grieving family who will carry out the tahlil. Tahlilan is held by the people of Lilinta village every day for 40 days. In the tahlil ritual, there are alms/gifts in the hope of easing the burden of financing the tahlil ritual by the grieving family. The facility is not rejected by the recipient, in this case, the grieving family.

\section{Sofkabom Ritual}

After the 7th day of dismantling the Koi, there are rules for dismantling the Koi, that is when the woman (wife) dies, the widows who dismantle the Koi are the widows, and when the husband dies, the widowers or elders who dismantle the Koi dismantle the Koi. Close relatives to neighbors who are present get the relics of the deceased. These items are items that the deceased often uses in their daily life.

The implementation of the Koi demolition ritual containing the relics of the deceased begins with a prayer performed by the village imam, and just no one can do its performance. This case is due to the myth about prohibiting people who are not widows or vice versa because they are considered capable of causing severe problems. This belief harms the person. This belief is a legacy of oral tradition stories, giving rise to mystical thoughts that must overcome issues that can arise due to the neglect of prohibitions. There are gifts from bereaved families. Gifts are the form of relics of the deceased placed on the Koi and give to the people present at that time. The donation received belongs to the recipient, namely those who were present to witness the dismantling of the Koi, and no one refused the gift.

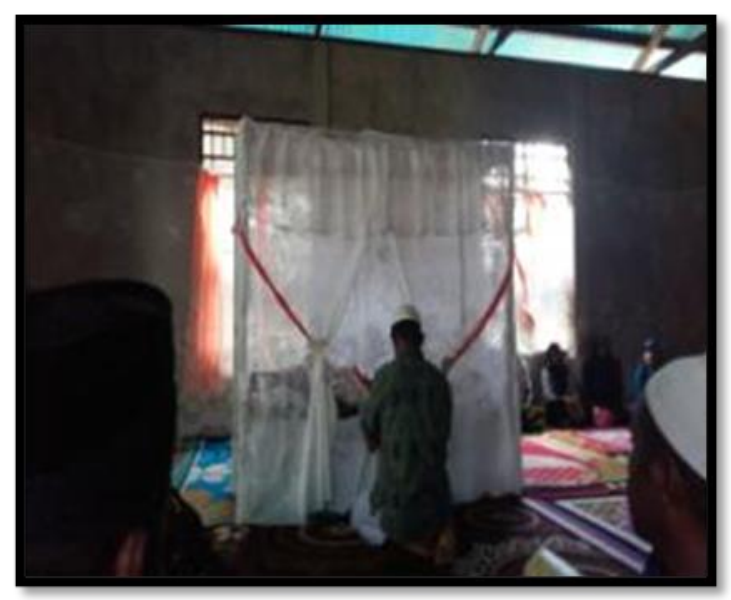

Figure 2.

Koi Dismantling Ritual

In times of grief, the people of Lilinta village voluntarily assist in the form of money to give the tahlil leader, the sara judge consisting of the village imam, modim and marbot. In the Mat Lou ethnic community in Lilinta village, a borrowing system applies without specifying a time limit for repayment due to the urgent need for people affected by disasters which residents must assist. So that it can create a sense of togetherness among people is one of the characteristics of traditional societies where there are no rules on when to return it. Only morals control and encourage individuals to accept general reciprocity as a truth that it should not violate.

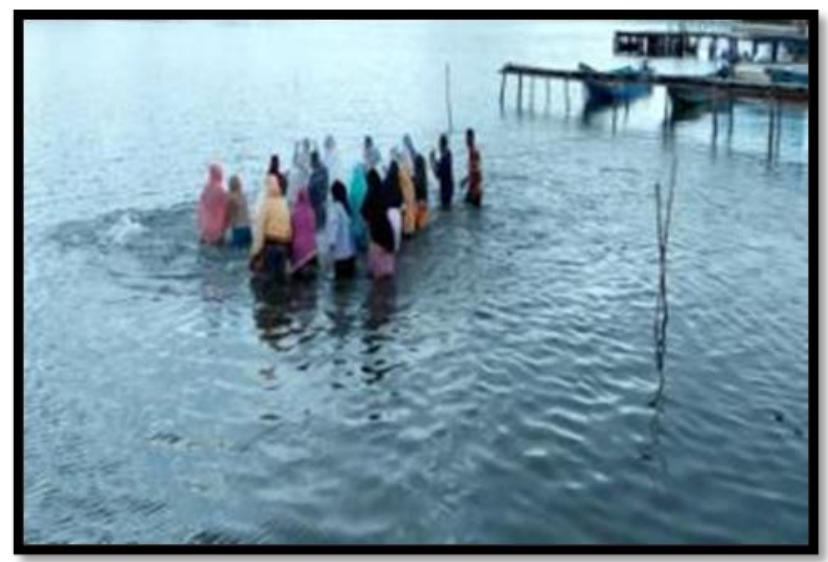

Figure 3.

Sof Kabom Ritual

After the 7th day, the Sof Kabom ritual (bone bath) at sea. Relatives assist in kind to those grieving, and on the 7th day, relatives begin to leave the grieving (not living at home with the grieving) before they make a tradition of mapontoriso (last meal). Implementing the Sof Kabom ritual can unite families to jointly dissolve all protracted sorrows and sorrows, return to activities as usual, and generate adequate energy in increasing motivation to maintain life. The Sof Kabom ritual signifies that all sadness will be washed away by seawater and brings joy 
together. In the end, the person concerned will be abandoned by his family to live his life as before.

\section{CONCLUSIONS}

$\mathrm{T}$ he entry of Islam from various regions illustrates the acceptance of new cultural elements in the Lilinta community in other rituals that complement funeral rituals. In religion, there are rules as interpretations and sources of social order, which means regulating people's lives, acting according to ideas and beliefs, and forming a symbol system to create solid feelings and motivations. Form a way to be implemented and embed it as a reality showing the principles, formulations, laws proclaimed by the Qur'an and the Sunnah of the Prophet. For generations, the Mat Lou community in Lilinta Village has interpreted various symbols that appear that complement the funeral rituals, which are features of the human body. In the funeral rituals, there was a fusion between religion and myths that formed local beliefs the Mat Lou ethnic community believed in Lilinta Village as an inseparable unit that became the face of Mat Lou ethnic Islam in Lilinta Village, West Misool District, Raja Ampat Islands. And the maintenance of general reciprocity in the event of an emergency in the community. Further research is needed to reveal the various traditions that exist in Lilinta Village so that the ancestral traditions, which are the identity of the indigenous people, are not easily lost. It takes the ability to ward off the brunt of outside culture that can tear the local Mat Lou ethnic culture in Lilinta Village. The need for support from various parties, both the community and local government, to develop local culture so that it is better known to both the local community and the wider community to become the selling point of tourism.

\section{E. ACKNOWLEDGMENT}

am so thankful for Jurnal Antropologi: Isu-Isu Sosial Budaya support to published my article and the other author.

\section{REFERENCES}

Ahimsa-Putra, H. S. (2012). Strukturalisme Levi-Strauss: Mitos dan Karya Sastra. Yogyakarta: Galang Printika.

Arwani, M. (2013). Transformasi Tradisi Berkat, Pergulatan Kelas Dan Status Sosial Dalam Ritual Mauludan. Menjaga Tradisi Dan Menggapai Pahala. Yogyakarta, Tici Publications.

Bourdieu, P. (2011). Choses Dites: Uraian dan Pemikiran, terj. Ninik Rochani Sjams, Yogyakarta: Kreasi Wacana.

Dillistone, F. W. (2002). The Power of Symbols. Kanisius.

Gusmao, M. G. (2012). da Silva. Hans-Georg Gadamer: Penggagas Filsafat Hermeneutik Modern yang Mengagungkan Tradisi. Yogyakarta: Kanisius.

Karim, A. (2017). Makna ritual kematian dalam tradisi Islam Jawa. Sabda: Jurnal Kajian Kebudayaan, 12(2), 161-171. https://doi.org/10.14710/sabda.12.2.161-171

Nawir, M. S., Yusuf, M., \& Kadir, A. (2020). Islam Raja Ampat dan Mitos Hantu Cuwig. SANGKEP: Jurnal Kajian Sosial Keagamaan, 3(1), 1-22. https://doi.org/10.20414/sangkep.v2i2p-ISSN

Nurrofika, N., \& Murdiono, M. (2020). Tradisi Hanta Ua Pua Sebagai Upaya Pelestarian Budaya Religi Di Bima. Jurnal Antropologi: Isu-Isu Sosial Budaya, 22(1), 10-18. https://doi.org/10.25077/jantro.v22.n1.p9-18

Pals, D. L. (2012). Seven Theories of Religion: Tujuh Teori Agama Paling Komprehensif. Jogyakarta: IRCiSoD.

Sari, L. M. (2018). Simbol Salib dalam Agama Kristen. Religi: Jurnal Studi Agama-agama, 14(2), 155-168. https://doi.org/10.14421/rejusta.2018.1402-01

Suwito, S., Hidayat, A., \& Agus, S. (2015). Tradisi dan Ritual Kematian Wong Islam Jawa. IBDA: Jurnal Kajian Islam Dan Budaya, 13(2), 6-25. https://doi.org/10.24090/ibda,v13i2.659

Syafrita, I., \& Murdiono, M. (2020). Upacara Adat Gawai Dalam Membentuk Nilai-Nilai Solidaritas Pada Masyarakat Suku Dayak Kalimantan Barat. Jurnal Antropologi: Isu-Isu Sosial Budaya, 22(2), 151-159. https://doi.org/10.25077/jantro.v22.n2.p151-159

Turner, B. S. (2012). Teori Sosiologi dari Klasik sampai Postmodern. Pustaka Pelajar.

Wallace, A. R. (2015). Sejarah Nusantara: The Malay Archipelago. Yogyakarta: Indolitersi Group.

Yaam, P., Asmuruf, V., Hassor, D., Yaam, A., \& Maniagasi, Y. (2012). Tradisi kematian masyarakat Ayamaru di Kabupaten Meibrat, Provinsi Papua Barat. Kementerian Pendidikan dan Kebudayaan, Balai Pelestarian Nilai Budaya

Yusuf, M., \& Nawir, M. S. (2021). Famari (Penghinaan Berujung Pada Tradisi Yang Mampu Menyebabkan Sanksi/Denda Adat, Tradisi Pada Masyarakat Misool Barat, Kepulauan Raja Ampat). SASI, 27(1), 1-11. https://doi.org/10.47268/sasi.v27i1.225

Yusuf, M., Sahudi, S., \& Muhandy, R. S. (2021). Komersialisasi Lahan Pertanian Di Koya Barat Dan Koya Timur, Kota Jayapura. Jurnal AGRISEP Kajian Masalah Sosial Ekonomi Pertanian dan 
Agribisnis, 20(01), 157-178. https://doi.org/10.31186/jagrisep.20.1.157-178

Yusuf, M., Sahudi, S., Sileuw, M., \& Safitri, L. (2021). Menata Kontestasi Simbol-Simbol Keagamaan di Ruang Publik Kota Jayapura. Religious: Jurnal Studi Agama-Agama dan Lintas Budaya, 5(2), 161-174. https://doi.org/10.15575/rjsalb.v5i2.10190 